\title{
Racism, Ideology, and Affirmative Action Revisited: The Antecedents and Consequences of "Principled Objections" to Affirmative Action
}

\section{Citation}

Federico, Christopher M., and James Sidanius. 2002. Racism, ideology, and affirmative action revisited: The antecedents and consequences of "principled objections" to affirmative action. Journal of Personality and Social Psychology 82, no. 4: 488-502

\section{Published Version}

http://dx.doi.org/10.1037/0022-3514.82.4.488

\section{Permanent link}

http://nrs.harvard.edu/urn-3:HUL.InstRepos:3200262

\section{Terms of Use}

This article was downloaded from Harvard University's DASH repository, and is made available under the terms and conditions applicable to Other Posted Material, as set forth at http:// nrs.harvard.edu/urn-3:HUL.InstRepos:dash.current.terms-of-use\#LAA

\section{Share Your Story}

The Harvard community has made this article openly available.

Please share how this access benefits you. Submit a story.

\section{Accessibility}




\section{Racism, Ideology, and Affirmative Action Revisited: The Antecedents and Consequences of "Principled Objections" to Affirmative Action}

\author{
Christopher M. Federico \\ University of Minnesota, Twin Cities Campus
}

\author{
Jim Sidanius \\ University of California, Los Angeles
}

\begin{abstract}
In 2 studies, the antecedents and consequences of "principled objections" to affirmative action (specific, "race-neutral" reasons for opposing the policy) among Whites were examined. In Study 1, data from a probability sample of Los Angeles adults indicated the following: (a) that principled-objection endorsement was driven not merely by race-neutral values but also by dominance-related concerns like racism; (b) that principled objections mediated the effects of group dominance; and (c) that education strengthened-rather than attenuated-the relationship between dominance-related concerns and principled objections, whereas it left the relationship between race-neutral values and the latter essentially unchanged. In Study 2, the education findings were conceptually replicated in a panel study of undergraduates: The completion of additional years of college boosted the correlation between racism and principled objections, whereas it had no effect on the predictive power of conservatism. These results provide support for a general group-dominance approach, which suggests that factors like racism continue to shape White opposition to race-targeted policies.
\end{abstract}

The political debate about racial policy in America has been accompanied by a related controversy among students of intergroup relations concerning the origins of White attitudes toward policies like affirmative action (Sears, Hetts, Sidanius, \& Bobo, 2000). Although there are a number of approaches to this question (e.g., Citrin \& Green, 1990; Kinder \& Sanders, 1996; McConahay, 1983; Sears, 1988), two have emerged as particularly important: (a) a principled-conservatism perspective (e.g., Sniderman \& Carmines, 1997; Sniderman \& Piazza, 1993; Sniderman, Piazza, Tetlock, \& Kendrick, 1991), which suggests that White opposition to affirmative action derives primarily from ideology and raceneutral values such as self-reliance and a preference for minimal government, particularly among the well informed and well educated and (b) a general group-dominance perspective (Federico \& Sidanius, 2000; Sidanius, Pratto, \& Bobo, 1996), which suggests that a desire to preserve the in-group's privileged position continues to affect White attitudes even among educated and wellinformed citizens.

Although a number of recent studies have compared the predictions made by each of these models (Federico \& Sidanius, 2000;

Christopher M. Federico, Department of Psychology, University of Minnesota, Twin Cities Campus; Jim Sidanius, Department of Psychology, University of California, Los Angeles.

A version of portions of this article was presented at the 23rd Annual Meeting of the International Society of Political Psychology, Seattle, Washington, July 2000. Support for parts of this project was provided by the Russell Sage Foundation and the Office of the Chancellor, University of California, Los Angeles. We thank David Sears, P. J. Henry, Shelly Gable, and Colin Wayne Leach for their comments and assistance.

Correspondence concerning this article should be addressed to Christopher M. Federico, Department of Psychology, University of Minnesota, Twin Cities Campus, 75 East River Road, Minneapolis, Minnesota 55455. E-mail: federico@umn.edu
Sidanius et al., 1996, 2000; Sniderman, Crosby, \& Howell, 2000), most of these studies have looked at only one aspect of White opposition to affirmative action, namely its direct relationship with some of the broader determinants of political behavior, such as ideology and racism. What studies of the two models have failed to provide is an examination of the specific, policy-based objections that opponents of affirmative action may have in mind when they think about the policy, how these considerations may figure into the reasoning chains that connect generalized attitudes like conservatism and racism with people's assessment of the policy, or how their role may vary with education. In this article, we attempt to fill this gap by providing a more sophisticated comparison of the two models than previous work has allowed-one that takes into account the role played by these specific policy beliefs.

\section{The Principled-Conservatism Perspective}

In light of the trend toward increased racial tolerance in the present era (e.g., Schuman et al., 1997; Sears, 1988), the principled-conservatism perspective suggests that racism and other dominance-oriented motives are no longer the primary antecedents of White attitudes toward race-targeted policies. Instead, proponents of this model suggest that "the contemporary argument over race is, at its core, a political argument," in which policy disputes "are given their fundamental shape by the institutions of the party system and the ideological contours of the larger American political landscape" (Sniderman et al., 2000, p. 276). Thus, political values, rather than racism, now provide the primary framework within which racial policies are understood and evaluated. As such, proponents of this model suggest that White opposition to race-targeted policies should be understood mainly in terms of ideology, concerns about fairness, and support for individualistic values. As Sniderman and Carmines (1997) have argued, 
a primary basis for the one-sided opposition to affirmative action which involves preferential treatment or explicit quotas is the belief that it is not fair to hire people for jobs or grant them admission to schools because they belong to a particular social group and not because they are the most qualified. (p. 33)

Accordingly, proponents of this model have argued that racism and other dominance-oriented attitudes should not predict opposition to affirmative action once the effects of conservatism and other race-neutral political values are accounted for and that support for these values should not be associated with stronger racial biases (Sniderman \& Carmines, 1997). Support for this argument comes from studies indicating that anti-Black affect is only weakly related to conservatism and opposition to race-targeted policies (Sniderman, Brody, \& Kuklinski, 1984; Sniderman et al., 1991), and from survey-based experiments suggesting that conservatives are not more likely to deploy a double standard against Blacks in the allocation of aid to disadvantaged members of various groups (Sniderman \& Carmines, 1997; Sniderman \& Piazza, 1993; Sniderman et al., 1991, 2000).

To be sure, the principled-conservatism model does not suggest that opposition to affirmative action will be completely independent of racism. However, it does contend that relationships of this sort are more likely to be found among the poorly educated (Sniderman et al., 1991). Because these individuals lack the sophistication necessary for the understanding of abstract ideological concepts and the formally-egalitarian ethos of American political culture, their racial-policy attitudes and their general orientation toward politics should be more heavily colored by factors like racial animus. In contrast, the knowledge possessed by welleducated respondents should allow them to frame their policy attitudes in terms of abstract principles and provide them with an awareness of the tolerant norms at the heart of the American creed, attenuating the impact of racism and crude judgments about the interests of one's in-group (Sniderman, Hagen, Tetlock, \& Brady, 1986; Sniderman et al., 1991; see also Campbell, Converse, Miller, \& Strokes, 1960; Lipset, 1960; McClosky \& Zaller, 1984; Selznick \& Steinberg, 1969). According to the principled-conservatism perspective, it is these individuals who should most clearly perceive the essential independence of racism and values like conservatism. Thus, for example, Jacoby (1994) argued that

Education also plays an important part in determining attitudes, but not simply because more education correlates with less racial prejudice: more educated whites are also more influenced by political ideas, thus amplifying the role of ideology and diminishing the relevance of race per se [italics added]. (p. 37)

Consistent with this reasoning, Sniderman and colleagues (Sniderman \& Piazza, 1993; Sniderman et al., 1991) have found that college-educated conservatives are not more likely than collegeeducated liberals to offer greater support for government guarantees of equal opportunity for women than for Blacks, although both conservatives and liberals among the poorly educated tend to care less about equal opportunity for Blacks.

\section{The General Group-Dominance Perspective}

A very different perspective on the interface between racism, ideology, and affirmative action is provided by what has been referred to as the general group-dominance approach (e.g., Federico \& Sidanius, 2000; Sidanius et al., 1996, 2000). Although this approach has taken a number of specific forms, they all share a basic set of assumptions, including the following ideas: (a) that societies tend to be organized as hierarchies of groups differing in power and status, (b) that politics is a competition between groups over scarce material and symbolic resources, and (c) that dominant groups often rely on a variety of collective representations (e.g., racism, individualism) to legitimize the disproportionate allocation of resources to members of dominant groups and thereby reinforce group inequality (Sidanius \& Pratto, 2001). ${ }^{1}$ These assumptions lead to predictions that differ considerably from those suggested by the principled-conservatism model. First, rather than being an isolated phenomenon or a mere case of negative affect toward certain groups, racism is rooted in a basic desire for group dominance that expresses itself in a variety of other forms, including group self-interest and a general preference for hierarchical relations among social groups. More broadly, rather than being largely orthogonal to one another, the dominance perspective suggests that racism, political values, and opposition to affirmative action may serve a similar purpose: the reinforcement of group-based hierarchies. In fact, the model suggests that the seemingly mainstream values emphasized by the principled-conservatism approach may simply mask desires for group dominance, serving as conduits for the effects of the latter on policy preferences (see Sidanius \& Pratto, 2001).

This reasoning implies that racism, conservatism, and opposition to race-targeted policies should be highly correlated with one another (Federico \& Sidanius, 2000; Sidanius et al., 1996). Consistent with this claim, a variety of evidence indicates that these clusters of variables are interrelated in a number of ways. Although conservatives may be no more likely than liberals to practice a group-based double standard in the allocation of resources, a sizable body of research suggests that direct measures of racism are, in fact, strongly correlated both with opposition to affirmative action and conservatism (for a review, see Sidanius et al., 1996, 2000). ${ }^{2}$ Similar results are found when other dominance-related variables, such as social dominance orientation, are substituted for racism in analyses of the above sort (Sidanius et al., 2000; see also Bobo, 2000; Sears, Henry, \& Kosterman, 2000).

Finally, and most important, the group-dominance perspective also takes issue with the assertion that racism, conservatism, and opposition to affirmative action should be less strongly related among the well-educated. Although it does not contest the wellestablished finding that education appears to reduce absolute levels of prejudice (Lipset, 1960; McClosky \& Zaller, 1984), the groupdominance model also suggests that educated individuals-who

\footnotetext{
${ }^{1}$ Among others, these include realistic group conflict theory (see Bobo, 1983, 1988; Sherif, 1966), the group-positions model (see Blumer, 1961; Smith, 1981), neoclassical hegemony models (see Gramsci, 1976; Marx \& Engels, 1846/1970), the racial oppression model (see Turner, Singleton, \& Musick, 1984), paternalistic-oppression models (see Jackman, 1994; see also van den Berghe, 1967), and social dominance theory (see Sidanius, 1993; Sidanius \& Pratto, 2001).

${ }^{2}$ Findings of this sort are also consistent with the repeated observation that implicit appeals to racial hostility have become more and more prominent in mainstream conservative political rhetoric since the $1960 \mathrm{~s}$ (see Ansell, 1997; Carmines \& Stimson, 1989; Murphy \& Gulliver, 1971).
} 
tend to have a better understanding of basic political concepts and the relationships among them (Bennett, 1988; Bishop, 1976; Delli Carpini \& Keeter, 1996; Stimson, 1975)—may find it easier to connect their attitudes toward group-relevant social policies with both the interests of their own groups and their attitudes toward the out-groups the policies are designed to benefit (Federico \& Sidanius, 2000; Sidanius \& Pratto, 2001; Sidanius et al., 1996).

At one level, this prediction is consistent with the idea that the added sophistication provided by education may simply allow dominance-oriented members of high-status groups to dispense with overt expressions of prejudice and deploy a subtler and more complex defense of their groups' interests (Jackman \& Muha, 1984). More broadly, however, it is also consistent with one of the chief findings of research on belief-system structure, namely the finding that educated, politically-knowledgeable individuals are typically more attuned to the implicational connections between different sets of beliefs (Judd \& Downing, 1990; Judd \& Krosnick, 1989; Lavine, Thomsen \& Gonzales, 1997; see also Converse, 1964; Stimson, 1975; Zaller, 1992). If the group-dominance model's assertion that racism, conservatism, and opposition to affirmative action share a common function is true, then this reasoning implies these variables should be more strongly interrelated among educated Whites. Consistent with these arguments, several studies have shown that both racism and other dominance-related variables (e.g., social dominance orientation [SDO]) are more strongly related to conservatism and opposition to affirmative action among well-educated and informed Whites than they are among poorly educated and poorly informed Whites (Federico \& Sidanius, 2000; Sidanius et al., 1996, 2000; see also Sears, van Laar, Carillo, \& Kosterman, 1997). Thus, the group-dominance model suggests that the effects of education may be more paradoxical than most researchers have typically assumed, reducing absolute levels of racism, on one hand, while simultaneously boosting the potency of those prejudices that remain.

\section{The Role of "Principled Objections" to Affirmative Action}

As this review suggests, research in the group-dominance tradition has cast serious doubt on some of the principledconservatism model's predictions about the relationships between racism, conservatism, and opposition to race-targeted policies. However, as we noted earlier, it is increasingly clear that these analyses have neglected an important element of the larger belief system behind opposition to affirmative action, namely the specific cognitions individuals may have in mind when they think about the policy (Bobo, 2000; Sears, Hetts, et al., 2000). Although studies conducted by advocates of both models have focused primarily on the relationship between predispositions like racism and conservatism and opposition to race-targeted policies, a number of scholars have suggested that affirmative-action attitudes may be mediated by a variety of principled objections that made their initial appearance in elite political discourse and have subsequently diffused to members of the mass public (see Federico, 2000; Gamson, 1992; Gamson \& Modigliani, 1987; Kinder \& Sanders, 1990). These include the following ideas: (a) that affirmative action consists of unfair preferences, (b) that it is reverse discrimination, and (c) that it stigmatizes the very people it aims to help (Bobo, 2000; Carmines \& Merriman, 1993; Roth, 1990; Sniderman \&
Piazza, 1993; Sears, Hetts, et al., 2000; Thernstrom \& Thernstrom, 1997; see also Gamson \& Modigliani, 1987).

Despite their emphasis on the broader determinants of opposition to race-targeted policies, neither theory seriously disputes the argument that elite-derived principled objections may play an important role in the origins of Whites' attitudes toward the policies. Although the role of these objections has perhaps been more heavily emphasized by proponents of the principledconservatism model (e.g., Sniderman et al., 2000), theorists in the group-dominance tradition generally do not object to the intuitive notion that specific beliefs about affirmative action may have important effects on attitudes toward the policy (Sidanius et al., 2000). However, the two models do offer different predictions about which generalized predispositions should lead individuals to endorse principled objections in the first place. On one hand, consistent with the idea that racism is no longer the primary force driving Whites' racial-policy attitudes, the principled-conservatism model suggests that support for these objections will stem largely from race-neutral political commitments. On the other hand, although not disputing the idea that such values should be relevant to policy-related beliefs, the dominance model implies that principled objections may also be influenced by attitudes linked to the maintenance of group hegemony.

Moreover, these basic predictions also suggest different mediating roles for principled objections in the overall process leading up to opposition to affirmative action. Although both models suggest that principled objections may mediate the relationship between generalized predispositions and affirmative-action opposition, they differ with respect to which predispositions they would expect the objections to mediate. Consistent with the idea that principled opposition to affirmative action is chiefly a function of political values, the principled-conservatism model suggests that attitudes like conservatism and individualism should be the primary ones in which effects are mediated by principled objections. However, in line with the suggestion that ostensibly race-neutral policy objections may in fact rationalize motives that are essentially dominance-oriented (Sidanius \& Pratto, 2001; see also Bobo, 2000), the group-dominance approach implies that racism and other dominance-related variables will also have a mediated effect on opposition to affirmative action via principled objections.

Finally, both models imply that education may have important effects on the relative importance of various antecedents of principled-objection endorsement. However, the two models again make very different predictions about what these effects should look like. On one hand, consistent with the idea that education should dampen the effects of group-oriented concerns and strengthen people's awareness of the incompatibility of prejudice and the basic norms of American political culture, the principledconservatism model suggests that dominance-related variables should be related to principled objections mainly among the poorly educated. On the other hand, consistent with the notion that education may strengthen respondents' understanding of the common, hierarchy-enhancing implications of racism, principled objections, and opposition to affirmative action, the group-dominance approach suggests that the effects of racism and other dominancerelated variables should, if anything, become more pronounced among the well-educated (e.g., Sidanius et al., 2000).

As noted earlier, issues such as these have not received a great deal of attention. Nevertheless, recent work has begun to provide 
suggestive evidence for each set of predictions. For example, in an experimental study of students' attitudes toward affirmative action, Bobocel, Son Hing, Davey, Stanley, and Zanna (1998) found that affirmative-action programs designed to violate certain norms (i.e., meritocracy and consistency of treatment) were opposed more strongly by individuals who endorsed these norms, a result consistent with principled-conservatism predictions. However, in line with group-dominance predictions, Bobocel et al. also found that prejudice was independently associated with program opposition, an effect that was mediated by the tendency to perceive the programs as justice-violating.

Unfortunately, although the Bobocel et al. (1998) study was able to shed light on some of the issues raised by each model, it was unable to address a number of others. For example, although ideology and individualism have been implicated both as direct determinants of which policy-related cognitions are salient to a given individual (Sniderman et al., 2000) and as vehicles for the influence of dominance-related factors (Sidanius et al., 2000; see also Federico, 2000), their effects were not examined in this study, leaving researchers with an incomplete look at the causal process suggested by each model. Moreover, although the experimental design used by Bobocel et al. did allow them to precisely gauge the effects of specific justice-violating aspects of affirmative-action programs, it did not permit a look at the full range of principled objections people may have in mind when thinking about affirmative action. For example, it looked only at support for one of the elite arguments that provide the framework for principled opposition to affirmative action (i.e., its possible lack of fairness) as opposed to concerns about reverse discrimination, minority stigmatization, and the like (Gamson, 1992). Additionally, it was unable to explore the cognitions individuals have in mind under "normal" conditions, with no inducement to think about affirmative action in specific terms. Finally, and most important, Bobocel et al.'s study, which relied on cross-sectional student samples, was unable to explore the key role of education. It is these concerns that we attempt to address in the present study.

\section{Overview of the Studies}

In summary, rather than simply looking at the relationship between generalized predispositions and opposition to affirmative action, the studies reported here attempt to compare the two models' predictions about the role of the specific, policy-relevant beliefs commonly thought to mediate this relationship. Perhaps more important, they also attempt to examine their divergent predictions about the role of education. To this end, we conducted two studies. Our first study relied on data from White respondents to the 1996 Los Angeles County Social Survey (LACSS). In this sample, we examined the overall pattern of causal relationships among political values, dominance-related variables, principled objections, and opposition to affirmative action, as well as the effects of education on the relative predictive power of raceneutral and dominance-related variables vis-à-vis principled objections. In our second study, we extended our investigation of the role of education in a longitudinal direction by examining changes in the relative importance of race-neutral and dominance-related variables as antecedents of support for principled objections in a sample of White students over the course of their college education. Because we were able to track individuals' attitudes over time in this study, we were able to get a closer look at the paradoxical effect of education (i.e., its tendency to reduce absolute levels of prejudice) while increasing the predictive power of prejudice with regard to actual racial-policy attitudes.

\section{Study 1}

\section{Method}

\section{Respondents and Procedure}

As noted above, the data for this study were taken from the 1996 LACSS. The LACSS is a large omnibus survey, conducted each spring by the Institute for Social Science Research (ISSR) at the University of California, Los Angeles (UCLA). Using a random digit dialing procedure, the ISSR contacts a random sample of Los Angeles adults for telephone interviews and assesses a wide assortment of variables, including general political attitudes, racial attitudes, attitudes toward a variety of social policies, and standard demographics. The 1996 sample consisted of 663 randomly selected adults from Los Angeles County. Of these, 206 were White, 209 were Black, 205 were Latino, and 43 were Asian American. Only the White respondents' data were used.

\section{Measures}

Using items from 1996 LACSS, we operationalized eight variables: conservatism, individualism, classical racism, group threat, social dominance orientation, opposition to affirmative action, principled objections to affirmative action, and educational attainment. A series of demographic variables were also included in the analyses. Unless otherwise indicated, each item used a 4-point response scale, ranging from 1 (strongly disagree) to 4 (strongly agree). Except for education and the demographics, all of these measures were recoded to run from 0 to 1 prior to the analyses. Descriptive statistics for these variables are shown in Table 1.

\section{Race-Neutral Political Values}

Political conservatism. This composite measure was based on two indices: (a) respondents' self-placement on a 5-point ideology scale, ranging from 1 (strong liberal) to 5 (strong conservative); and (b) a summary index of respondents' partisan identification, which also formed a 5-point scale, ranging from 1 (strong Democrat) to 5 (strong Republican). Both indices were coded such that higher scores indicated greater conservatism $(\alpha=.67)$.

Individualism. This variable measured support for the value of selfreliance and the belief that success is primarily a function of individual effort. It was indexed using two items: (a) "Although there was discrimination in the past, today members of all groups have an equal opportunity to succeed"; and (b) "Success, or one's achievement, in American society depends primarily on individual merit." Higher scores indicated greater individualism $(\alpha=.67)$.

\section{Group-Dominance Variables}

Classical racism. This variable measured the degree to which respondents exhibited "old-fashioned," dominance-oriented prejudices toward Blacks (see Sidanius et al., 1996; Sidanius, Pratto, Martin, \& Stallworth, 1991). Respondents were given a list of reasons "some people give" to explain why Blacks are worse off than Whites and asked to indicate how much they agreed or disagreed with each. Responses to two of these reasons were included in the scale: (a) "Because Blacks have less in-born ability to learn" and (b) "Because most Blacks just don't have the moti- 
Table 1

Intercorrelations for Variables From the 1996 Los Angeles County Social Survey (Study 1)

\begin{tabular}{lccccccccc}
\hline \multicolumn{1}{c}{ Variable } & $M$ & $S D$ & 1 & 2 & 3 & 4 & 5 & 6 & 7 \\
\hline 1. Principled objections & 2.71 & 0.91 & - & & & & & \\
2. Political conservatism & 2.98 & 1.04 & .42 & - & & & & \\
3. Individualism & 2.88 & 0.84 & .45 & .38 & - & & & \\
4. Classical racism & 1.73 & 0.66 & .36 & .29 & .20 & - & & \\
5. Group threat & 1.69 & 0.69 & .37 & .20 & $.13^{\mathrm{a}}$ & .48 & - & \\
6. Social dominance orientation & 1.56 & 0.46 & .36 & .28 & $.13^{\mathrm{a}}$ & .44 & .40 & - & \\
7. Opposition to affirmative action & 2.50 & 1.03 & .61 & .42 & .27 & .29 & .27 & .35 & - \\
\hline
\end{tabular}

${ }^{\text {a }}$ Correlations not significant at the $p<.05$ level. All other correlations were significant at the $p<.01$ level.

vation or willpower to pull themselves out of poverty." Higher scores indicated greater racism $(\alpha=.45){ }^{3}$

Group threat. This variable measured the degree to which respondents believed that Blacks posed a threat to other groups in the competition for valued social resources such as jobs, housing, and political power (see Bobo, 1988, 2000). Four items were included in the scale: (a) "More good jobs for Blacks means fewer good jobs for members of other groups"; (b) "The more influence Blacks have in local politics, the less influence members of other groups will have in local politics"; (c) "The more good housing and neighborhoods go to Blacks, the fewer good houses and neighborhoods there will be for members of other groups"; and (d) "Many Blacks have been trying to get ahead academically at the expense of members of other groups." Higher scores indicated greater levels of perceived threat $(\alpha=.76)$.

Social dominance orientation. Social dominance orientation-a dimension reflecting the degree to which individuals prefer hierarchical relations between groups in society-was measured using the complete 16-item Social Dominance Orientation Scale (Sidanius \& Pratto, 2001). Extensive psychometric work has shown this scale to be highly reliable and valid, as well as distinguishable from related dimensions, such as rightwing authoritarianism (Pratto, Sidanius, Stallworth, Malle, 1994; Sidanius \& Pratto, 2001; see also Altemeyer, 1998; McFarland \& Adelson, 1996; Whitley, 1999). Higher scores indicated higher SDO $(\alpha=.84)$.

\section{Racial Policy Measures}

Opposition to affirmative action. This was measured with a single item asking respondents to answer the following question: "Do you support or oppose affirmative action?" Higher scores indicated greater opposition to affirmative action.

Principled objections to affirmative action. This variable assessed the degree to which respondents believed that a series of "principled," raceneutral objections to affirmative action were important to their overall opinion on the issue. The respondents were asked to indicate how central a series of policy considerations were to their beliefs about affirmative action. Before they were asked about the importance of each objection, respondents were read the following stem: "People give many reasons for their position on affirmative action. I am going to read you some of these reasons. For each one, please tell me how important this reason is for your position on affirmative action." Although respondents gave their opinions on six considerations, only the four that dealt specifically with principled reasons for opposing affirmative action that have become prominent in elite discourse-and that have been picked up by opponents in the mass public (Gamson, 1992; Sniderman \& Carmines, 1997; see also Roth, 1990; Thernstrom \& Thernstrom, 1997)—were included in the measure: (a) "Affirmative action is reverse discrimination," (b) "Affirmative action is basically unfair," (c) "Affirmative action will increase racial conflict," and (d) "Affirmative action just increases the idea that certain groups are not as good as others." Respondents rated the importance of each of these "principled objections" on a 4-point scale, ranging from 1 (very important reason) to 4 (not at all an important reason). These items were reversecoded and then averaged; higher scores indicated that principled objections to affirmative action were more important to respondents' beliefs about the issue $(\alpha=.84)$.

Educational attainment. This was indexed using six educational categories: no high school diploma, high school graduate, some college (with no higher degree), junior or community college degree, BA or BS degree (with no advanced degree), and advanced degree.

Demographics. The analyses also included three demographic variables: age, gender, and income.

\section{Results}

\section{Preliminary Analyses}

The intercorrelations among the variables are shown in Table 1. Here, there are several interesting preliminary results. First, consistent with assumptions of both models, "principled-objection" endorsement was related to affirmative-action opposition $(r=.61$, $p<.0001)$. Because both models assume that the effects of principled objections should be proximal to those of generalized predispositions like conservatism and racism, we also looked at whether the relationship between the two variables remained strong once conservatism, individualism, and the three groupdominance variables were added to the analysis. Consistent with this assumption, the addition of these variables only slightly reduced the relationship between principled objections and opposition to affirmative action $(r=.50, p<.0001)$.

Further inspection of the coefficients in Table 1 also provides some evidence for the group-dominance model's assumption that racism is essentially an expression of group dominance with close ties to other group-interested variables. Here, it can be seen that racism was strongly related both to group threat $(r=.48, p<.01)$ and to social dominance orientation $(r=.44, p<.01)$. Moreover, the correlation between group threat and SDO was also fairly strong $(r=.40, p<.01)$. Confirming this pattern of intercorre-

\footnotetext{
${ }^{3}$ Although a reliability of .45 is relatively low in absolute terms - and in comparison with the reliabilities for the race-neutral variables-it is not unusual to observe reliabilities of this magnitude with short scales within probability samples, as opposed to samples of university students (especially with regard to racial-attitude measures; see Sears et al., 1997). Furthermore, to the extent that this low reliability is a source of bias, the bias would go against our hypothesis, because it would actually attenuate the correlation between racism and other variables. This is especially the case when one remembers that the reliabilities of the race-neutral scales were higher, reducing the likelihood of an attenuation of their effects.
} 
lations, a reliability analysis using standardized versions of each scale indicated that the three measures hung together well (i.e., $\alpha=.71$ ). Thus, the three group-dominance variables do appear to form something of a unit.

\section{Principled Objections to Affirmative Action: Antecedents and Causal Significance}

Although the above results suggest that principled objections are a strong predictor of opposition to affirmative action, the question of where these principled objections come from in the first place still remains. To address this question, we estimated three regression models, in which principled objections were regressed on the demographics, conservatism, individualism, and classical racism (Model 1), group threat (Model 2), or SDO (Model 3). The results of these analyses can be found in Table 2. Consistent with our expectations based on the principled-conservatism model, conservatism and individualism were significantly related to principled objections to affirmative action in all three models (all $p s<.001$ ), even after the effects of each group-dominance variable were taken into consideration. However, a look at the coefficients for our three group-dominance variables shows a pattern more consistent with the group-dominance model: Racism $(b=.29, \beta=.20, p<.01)$, group threat $(b=.39, \beta=.27, p<.001)$, and $\operatorname{SDO}(b=.41, \beta=$ $.25, p<.001)$ each predicted significant variance in principled objections to affirmative action, even after the effects of conservatism and individualism were taken into account. Thus, although race-neutral variables do have an influence on principled objections, a fact that neither model would dispute, desires for group dominance are clearly relevant to principled objections, as proponents of the dominance model have argued. Of course, this analysis of the antecedents of principled objections provides us with a look at only one part of a much broader empirical canvas. More precisely, the two models suggest that principled objections to affirmative action will play different roles in the overall pattern of

\section{Table 2}

Importance of Principled Objections to Affirmative Action Regressed on Political Conservatism, Individualism, and Classical Racism (Model 1), Group Threat (Model 2), and Social Dominance Orientation (Model 3; Study 1, 1996 Los Angeles County Social Survey)

\begin{tabular}{|c|c|c|c|c|}
\hline Model \& variable & $B$ & $S E B$ & $\beta$ & $R^{2}$ \\
\hline \multicolumn{5}{|l|}{1} \\
\hline Political conservatism & $.29 * * *$ & .08 & .26 & \multirow[t]{3}{*}{$.359 * *$} \\
\hline Individualism & $.35 * * *$ & .07 & .32 & \\
\hline Classical racism & $.29 * *$ & .09 & .20 & \\
\hline \multicolumn{5}{|l|}{2} \\
\hline Political conservatism & $.31 * * *$ & .08 & .27 & \multirow[t]{3}{*}{$.380 * *$} \\
\hline Individualism & $.34 * * *$ & .07 & .31 & \\
\hline Group threat & $.39 * * *$ & .09 & .27 & \\
\hline \multicolumn{5}{|l|}{3} \\
\hline Political conservatism & $.28 * * *$ & .08 & .25 & \multirow[t]{3}{*}{$.357 * * *$} \\
\hline Individualism & $.32 * * *$ & .08 & .29 & \\
\hline Social dominance orientation & $.41 * * *$ & .11 & .25 & \\
\hline
\end{tabular}

Note. $B \mathrm{~s}, S E \mathrm{~s}$, and cumulative $R^{2}$ statistics are from equations containing all three predictors in each model, education, and the demographic variables.

$* * p<.01 . \quad * * * p<.001$. relationships connecting generalized predispositions with affirmative-action opposition. Although both models contend that principled objections should mediate the relationship between these broader attitudes and opposition to affirmative action, the principled-conservatism model suggests that principled objections should primarily mediate the effects of race-neutral political values, whereas the group-dominance approach implies that they should also mediate the effects of various dominance-related motives.

In an effort to reinforce our regression results, and expand on them by looking at the overall role played by principled objections in the process leading up to affirmative-action opposition, we estimated a linear structural relations (LISREL) maximumlikelihood structural equation model (Jöreskog \& Sörbom, 1993). In this model, conservatism, individualism, and principled objections were specified as latent factors indicated by the individual items in each scale, whereas the single-item index of opposition to affirmative action was included as a measured variable. Because racism, group threat, and social dominance orientation can be thought of as manifestations of a single underlying dimension corresponding to desires for group dominance (Federico \& Sidanius, 2000; Sidanius, 1993; Sidanius et al., 1996), the scales for each these variables were used as the three indicators of a latent group-dominance factor. Following the customary procedure (see Jöreskog \& Sörbom, 1993), we set the metric of each latent factor by fixing one of its loadings to 1 . In the model, conservatism, individualism, and group dominance were specified as correlated exogenous variables, whereas principled objections and opposition to affirmative action were regarded as endogenous variables. Conservatism, individualism, and group dominance were allowed to have direct effects on principled objections, and opposition to affirmative action was assumed to be a function of conservatism, group dominance, and principled objections. ${ }^{4}$

The results for this model are shown in Figure 1 with unstandardized parameter estimates. On the whole, the model provided an acceptable fit to the data, $\chi^{2}(45)=55.26, p=.14$, adjusted goodness-of-fit index $(\mathrm{AGFI})=.91$. Consistent with our preliminary analyses, principled objections were related to affirmative action opposition $(b=.53, p<.001)$, net of the effects of conservatism and group dominance. Also, as before, we found that the latent factors corresponding to conservatism and individualism were both related to principled objections $(b=.30, p<.10$, and $b=.38, p<.01$, respectively), although the effect of conservatism was only marginal when the effects of the other variables were

\footnotetext{
${ }^{4}$ Two additional points about the specification of this model are worth mentioning here. First of all, although individualism was related to affirmative-action opposition in this dataset $(b=.24, p<.01$ ), preliminary analyses indicated that this relationship was completely mediated by principled objections and conservatism (reducing the net relationship to nonsignificance; $b=-.09, p>.10$ ). Therefore, the model did not include a direct path from individualism to affirmative-action opposition. Secondly, on the basis of information provided by LISREL's modification-index feature (Jöreskog \& Sörbom, 1993), the errors for two of the indicators of principled objections were allowed to correlate. These were the errors for the items asking about affirmative action as "reverse discrimination" and the likelihood that affirmative action reinforced the perception that some groups were not as good as others; these errors correlated at $\theta=-.15(p<$ $.05)$.
} 


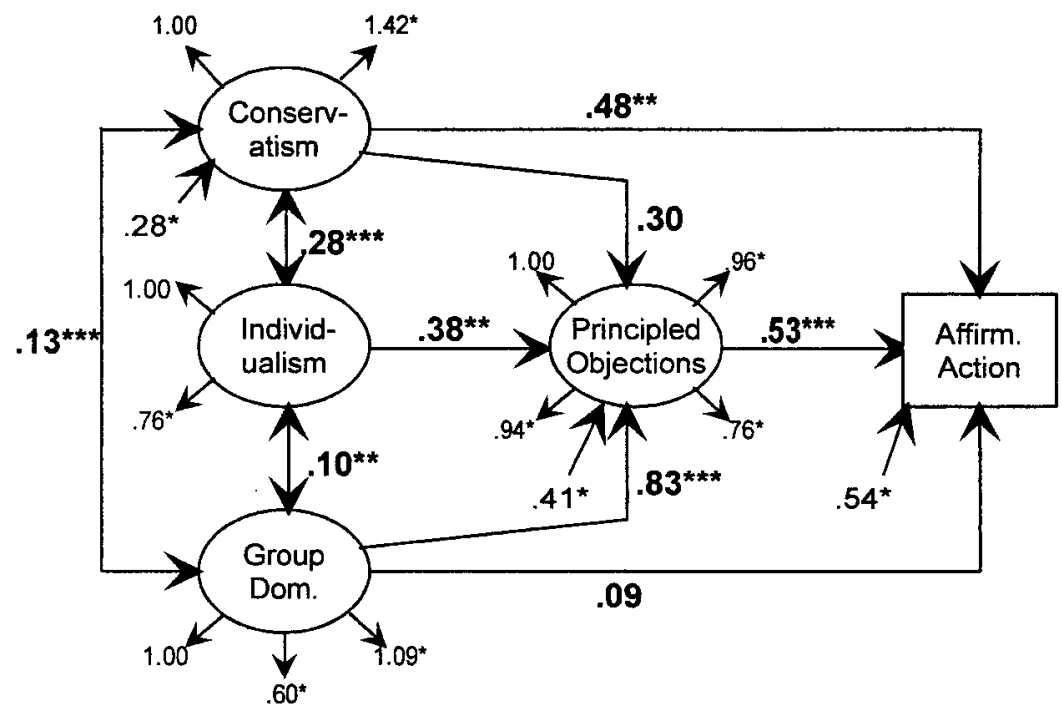

Figure 1. Linear structural relations estimates for the overall causal model (Study 1, 1996 Los Angeles County Social Survey). Dom. $=$ dominance; Affirm. $=$ affirmative. $\chi^{2}(45)=55.26, p=.14$, adjusted goodness-of-fit index $=.91 . * p<.05 . \quad * * p<.01 . \quad * * * p<.001$.

considered. This is a result generally consistent with the principled-conservatism model. Indeed, constraining either of these two paths to zero produced a significant decline in model fit, $\Delta \chi^{2}(1)=3.15, p<.05$, for conservatism; $\Delta \chi^{2}(1)=8.19, p<.01$, for individualism, although only the constraint on the effect of individualism reduced the overall fit of the model to nonsignificance (albeit just barely; i.e., $\chi^{2}[46]=63.45, p=.045$ ). However, contrary to the assumptions of the principled-conservatism approach-but consistent with group-dominance predictions- the estimates shown in Figure 1 also indicate that group dominance had a considerable effect on principled objections $(b=.83, p<$ .001 ), one that was far larger than the effect of either race-neutral factor. Consistent with this result, an additional analysis indicated that constraining the effect of group dominance to zero produced a significant and relatively large decline in model fit, $\Delta \chi^{2}(1)=12.70, p<.001$, effectively reducing the overall fit of the model to nonsignificance, $\chi^{2}(46)=67.96, p<.02$. Finally, consistent with the idea that conservatism, individualism, and various ideologies of group dominance may share common, hierarchy-enhancing features, both conservatism and individualism were significantly correlated with the group-dominance factor $(\varphi=.13$, and $\varphi=.10$, respectively; both $p \mathrm{~s}<.01)$. Moreover, constraining these two covariances to zero produced a significant decline in model fit, $\Delta \chi^{2}(2)=20.28, p<.001$, reducing the overall fit of the model to nonsignificance, $\chi^{2}(47)=75.54, p<$ .01 .

An analysis of the indirect effects of each exogenous variable on opposition to affirmative action via principled objections reinforced this pattern of findings. Here, the estimates for the overall model revealed that only one of the race-neutral variables, individualism, had a fully significant indirect effect on opposition to affirmative action (indirect effect $[I E]=.20, p<.05$ ). The indirect effect of conservatism was only marginal $(I E=.16, p<$ .10). In contrast, group dominance had a sizable indirect effect on affirmative action opposition $(I E=.43, p<.01)$. As such, this suggests that the causal process leading up to affirmative action opposition cannot ignore the effect of dominance-related variables on the endorsement of principled objections.

\section{The Role of Education}

Although these results are certainly instructive, they leave one of our most important concerns - the role of education- unaddressed. To explore the role of this key variable, we looked at the antecedents of principled objections to affirmative action separately among Whites who were low and high in educational attainment. Following a methodology used in earlier studies (e.g., Sidanius et al., 1996; Sniderman \& Piazza, 1993), we divided the sample into a low-education group consisting of respondents with no college degree $(n=118)$ and a high-education group consisting of respondents with at least a community college degree $(n=88)$. For each of the three models, the principled-objections index was then regressed separately on the demographics, conservatism, individualism, and the dominance variable included in that model. In a further analysis, the groups were combined, and differences in the relationship between each attitude and principled objections across the groups were tested by examining the coefficients for the interactions between each attitude and education.

The results of these analyses are displayed in Table 3. Looking first at the multivariate results for the two "race-neutral" predictors in each of the models, we find a pattern that is inconsistent with the principled-conservatism model's predictions about the effects of education. Once the effects of the dominance variables are accounted for, the coefficients corresponding to the relationship between conservatism and principled objections actually appear to become smaller as respondent education increases $(b=.28$ vs. $b=$ .17 , in Model $1 ; b=.30$ vs. $b=.24$, in Model $2 ; b=.30$ vs. $b=$ .21 , in Model 3), although the coefficients for individualism appear to increase slightly ( $b=.33$ vs. $b=.38$, in Model $1 ; b=.30$ vs. $b=.40$, in Model $2 ; b=.29$ vs. $b=.37$, in Model 3 ). However, 
Table 3

Importance of Principled Objections to Affirmative Action Regressed on Political Conservatism, Individualism, and Classical Racism (Model 1), Group Threat (Model 2), and Social Dominance Orientation (Model 3) at Low and High Levels of Education (Study 1, 1996 Los Angeles County Social Survey)

\begin{tabular}{|c|c|c|c|c|c|c|c|c|}
\hline \multirow[b]{3}{*}{ Model \& variable } & \multicolumn{3}{|c|}{ Low education $(n=118)$} & \multicolumn{3}{|c|}{ High education $(n=88)$} & & \\
\hline & \multirow[b]{2}{*}{ Bivariate $B$} & \multicolumn{2}{|c|}{ Multivariate } & \multirow[b]{2}{*}{ Bivariate $B$} & \multicolumn{2}{|c|}{ Multivariate } & \multicolumn{2}{|c|}{ Slope test } \\
\hline & & $B$ & $S E B$ & & $B$ & $S E B$ & $B$ & $S E B$ \\
\hline \multicolumn{9}{|l|}{1} \\
\hline Conservatism & $.27 * *$ & $.28 * *$ & .10 & $.58 * * *$ & .17 & .13 & -.09 & .16 \\
\hline Individualism & $.33 * * *$ & $.33 * *$ & .10 & $.56 * * *$ & $.38 * * *$ & .11 & .04 & .15 \\
\hline Classical racism & $.19 \dagger$ & .13 & .11 & $.89 * * *$ & $.63 * * *$ & .16 & $.54 * *$ & .19 \\
\hline Adjusted $R^{2}$ & & .170 & & & .424 & & & \\
\hline \multicolumn{9}{|l|}{2} \\
\hline Conservatism & - & $.30 * *$ & .10 & - & $.24 \dagger$ & .12 & -.03 & .16 \\
\hline Individualism & - & $.30 * *$ & .10 & - & $.40 * * *$ & .11 & .09 & .15 \\
\hline Group threat & $.25 *$ & $.25 *$ & .12 & $.77 * * *$ & $.60 * * *$ & .14 & $.39 *$ & .18 \\
\hline Adjusted $R^{2}$ & & .174 & & & .450 & & & \\
\hline \multicolumn{9}{|l|}{3} \\
\hline Conservatism & - & $.30 * *$ & .11 & - & .21 & .14 & -.07 & .17 \\
\hline Individualism & - & $.29 * *$ & .10 & - & $.37 * *$ & .12 & .07 & .16 \\
\hline Social dominance orientation & $.39 * *$ & $.32 *$ & .14 & $.76^{* * * *}$ & $.53 * *$ & .18 & .22 & .22 \\
\hline Adjusted $R^{2}$ & & .197 & & & .337 & & & \\
\hline
\end{tabular}

Note. Multivariate entries for low and high education groups are taken from equations containing the three attitudes in each model and the demographic variables. Tests of slope differences are based on the unstandardized regression coefficients for each interaction term. $\dagger p<.10 . * p<.05 . * * p<.01 . * * * p<.001$

the tests on the interactions between each of these variables and education did not reach significance in any of the models (all $p$ s $>$ .10), suggesting that the magnitude of the relationship between each of the "race-neutral" variables and principled objections remains essentially consistent across educational levels.

Turning to the coefficients for the group-dominance factors, we found a pattern that was even less consistent with the principledconservatism model. In Model 1, we found that the net relationship between racism and principled objections was nonsignificant among the poorly educated $(b=.13, p>.10)$ but highly positive and significant among the well-educated $(b=.63, p<.001)$. Moreover, the difference between these coefficients was significant (interaction $b=.54, p<.01$ ). In the case of Model 2, we found a similar pattern: The net relationship between group threat and principled objections is larger among the highly educated $(b=$ $.60, p<.001)$ than among the poorly educated $(b=.25, p<.05)$, a difference that also reached significance (interaction $b=.39$, $p<.05)$. Finally, in Model 3, we found that the relationship between SDO and principled objections was noticeably larger among the highly educated $(b=.53, p<.01)$ than among the poorly educated $(b=.32, p<.05)$, although this difference was not significant $(b=.22, p>.10)$.

Although these findings are informative, the comparison of regression coefficients across groups carries with it the possibility that the differences between the coefficients may have resulted from higher levels of measurement error in the low-education group (cf. Judd, Krosnick, \& Milburn, 1981; Judd \& Milburn, 1980). That is, the key variables in the models may have been measured less reliably in the low-education group, artifactually depressing the relationships between principled objections and their antecedents (Pedhazur, 1997). To deal with this problem and provide an overall look at the effects of education, a summary analysis of the role of education was conducted using a series of LISREL multigroup structural equation models (Jöreskog \& Sörbom, 1993). In these analyses, the causal model tested earlier was estimated separately within the low- and high-education groups. In three successive LISREL runs, the path from one of the three basic predictors (i.e., conservatism, individualism, or group dominance) to principled objections was constrained to equality across the two groups. Like the interactions tested above, this procedure allowed us to see whether the strength of the relationship between each predictor and principled objections varied across the two groups. However, because these models look at the relationship between latent variables - assumed to reflect error-free "true scores"rather than measured variables, they are not faced with the problem of differential reliability across groups (Jöreskog \& Sörbom, 1993).

The results of these analyses are summarized in Table 4 using unstandardized parameter estimates. Looking first at the coefficients for the relationships between the two race-neutral values and principled objections, we again found a result that is generally at odds with the principled-conservatism perspective. More precisely, the effect of conservatism on principled objections again appeared to decline with education: Although it was positive and marginally significant in the low-education group $(b=0.53, p<$ $.10)$, it actually became negative-although not significantly so-in the high-education group $(b=-0.20, p>.10)$. The effect of individualism, on the other hand, did appear to increase with education (i.e., $b=0.31, p>.10$, in the low-education group vs. $b=0.54, p<.05$, in the high-education group). However, as the 
Table 4

Multigroup Structural-Equation Analysis of the Effects of

Conservatism, Individualism, and Group Dominance on

Principled Objections to Affirmative Action at Low

and High Levels of Education (Study 1, 1996

Los Angeles County Social Survey)

\begin{tabular}{cccccc}
\hline & & & \multicolumn{2}{c}{$\begin{array}{c}\text { Constrained } \\
\text { model }\end{array}$} \\
\cline { 5 - 6 } Effect of & $\begin{array}{c}\text { Low } \\
\text { education }\end{array}$ & $\begin{array}{c}\text { High } \\
\text { education }\end{array}$ & $\chi^{2}(91)$ & $p$ \\
\hline $\begin{array}{c}\text { Conservatism on } \\
\text { principled objections }\end{array}$ & $.53 \dagger$ & -.20 & 113.13 & .06 \\
$\begin{array}{c}\text { Individualism on } \\
\text { principled objections }\end{array}$ & .31 & $.54 *$ & 110.06 & .09 \\
$\begin{array}{c}\text { Group dominance on } \\
\text { principled objections }\end{array}$ & .72 & $2.92^{*}$ & 115.08 & $<.05$ \\
\hline
\end{tabular}

Note. Entries for the low and high education columns are unstandardized linear structural relations parameter estimates. Entries in the $\chi^{2}$ column refer to the fit of the overall multigroup model in which the indicated path was constrained to equality across the two groups.

$\dagger p<.10 . * *<.05$.

nonsignificant chi-square statistics in the last column of Table 3 indicate, constraining these two relationships to equality across groups did not significantly reduce the overall fit of the multigroup model in either case (i.e., $p=.06$, and $p=.09$, respectively). In contrast, the effect of group dominance on principled objections appeared to increase markedly across the two groups: Although it failed to reach significance at all in the low-education group $(b=0.72, p>.10)$, it was strong and positive in the higheducation group $(b=2.92, p<.05)$. Moreover, as Table 3 indicates, constraining this path to equality across the two groups did produce a significant decrement in overall fit $(p<.05)$, suggesting that the strength of this relationship is indeed reliably larger in the high-education group. ${ }^{5}$

In general, then, these results are more supportive of the general group-dominance model. Contrary to the principled-conservatism hypothesis, group-dominance considerations were more (rather than less) related to the endorsement of principled objections to affirmative action among the highly educated, even after the effects of conservatism and individualism were accounted for. Moreover, the relationship between each of the latter two variables and principled objections did not increase with education.

\section{Study 2}

Although these results provide some insight into the dynamics of principled opposition to affirmative action, they also have certain limitations, particularly with regard to our key prediction about the role of education. More precisely, our analysis of the effects of education on the relationship between race-neutral political values, dominance-related concerns, and principled objections-as well as previous analyses of education in this area (Sidanius et al., 1996; Sniderman \& Piazza, 1993)—relied on cross-sectional data, in which the attitudes of groups differing in education were compared. In contrast, the longitudinal, withinsubject effects of higher education have not been examined. Nevertheless, an analysis of this sort may help clarify issues that are difficult to address using cross-sectional data. Most important, although both perspectives suggest that changes directly associated with the educational process should produce the shifts in attitude organization predicted by each, comparisons of respondents differing in educational attainment give a look only at the end result of this process; they do not allow researchers to directly trace differences in belief organization to the educational experience. Moreover, they do not allow researchers to deal with the possibility that other aspects of the divergent life trajectories of respondents differing in educational attainment are responsible for the differences in attitude structure predicted by each model. Finally, given that both the principled-conservatism approach and others have often suggested that of all educational experiences exposure to college has perhaps the strongest effects on the development of tolerance (Sniderman et al., 1984, 1991; Sniderman \& Piazza, 1993; see also McClosky \& Zaller, 1984; Selznick \& Steinberg, 1969), we felt it was important to examine what happened to attitudes during the college period in particular. In an effort to deal with these issues, we turned to data from an ongoing panel study of intergroup attitudes among students at UCLA, which allowed us to directly examine changes in the relationship between raceneutral values, group-relevant concerns, and principled objections in the same group of individuals over several years of college.

\section{Method}

\section{Respondents and Procedure}

The data used in these analyses were collected as part of a ongoing panel study of the development of intergroup attitudes over the course of the college experience. In this analysis, data from only two waves were examined. The timing of each of these panels allowed us to examine the relationships between the variables of interest at a baseline time prior to the college experience and at a time after which the effects of higher education should have begun to emerge. Data for the first wave were collected in the summer of 1996 during orientation sessions for incoming freshmen at UCLA. During this wave, 2,157 respondents (78\% of the eligible students who attended the orientations) completed a written questionnaire asking about a variety of social, political, and campus-related issues. This sample consisted of 748 Whites, 68 Blacks, 255 Latinos, 753 Asian Americans, and 333 members of other ethnic groups (e.g., Native Americans, those of Middle Eastern descent). Of these, $44 \%$ were male and $56 \%$ were female. Data for the second wave we examined were collected approximately 2 years later, during the spring of 1998 (at the end of the students' sophomore year). During this wave, 1,390 (64\%) of the students from the first wave completed telephone interviews-conducted by the Computer-Assisted Telephone Interview unit at UCLA's Institute for Social Science Research-remeasuring many of the same variables assessed during the earlier wave of the study. ${ }^{6}$ Only data from the White participants who gave complete responses to all relevant items in both waves were used, resulting in a final sample of 372 individuals. Of these, $50 \%$ were male and $50 \%$ were female.

\footnotetext{
${ }^{5}$ Additional multigroup analyses indicated that none of the other paths in the model differed significantly across the two groups (all $p s>.05$ ).

${ }^{6}$ The second wave we examined also included a number of respondents who were added to the study after the first wave. Because these respondents did not complete the essential first-wave measures, they were excluded from the analyses.
} 


\section{Measures}

The logistics of the panel study made it difficult to obtain measures as detailed and varied as those included in Study 1. However, we were able to generate measures of the following: (a) political conservatism (a raceneutral political value), (b) classical racism (a dominance-related attitude), and (c) principled objections to affirmative action in the university context.

Political conservatism. This variable was indexed using the same two items in each wave: (a) "How would you describe your political party preference?" and (b) "How would you describe your general political outlook?" Responses were given on 7-point scales, ranging from 1 (strong Democrat or very liberal) to 7 (strong Republican or very conservative). Higher scores indicated greater conservatism $(\alpha=.86$, in 1996; $\alpha=.54$, in 1998).

Classical racism. Two items measuring prejudice-related attitudes were included in both waves. These were used to construct a measure of classical racism that differed slightly from the one used in Study 1. Rather than focusing on explanations for Black disadvantage, these items looked at opposition to close contact with members of other ethnic groups-an orientation that a variety of researchers have identified as a closely related component of prejudice in its classical, "old-fashioned" form (Sidanius \& Pratto, 2001; Sidanius et al., 1996; see also Biernat \& Crandall, 1999; Pettigrew \& Meertens, 1995; Schuman, Steeh, Bobo, \& Krysan, 1997; Sears, 1988). These items included the following: (a) "Interethnic dating should be avoided" and (b) "Interethnic marriage should be avoided." Responses were given on a 7-point scale ranging from 1 (strongly disagree) to 7 (strongly agree). Higher scores indicated greater racism ( $\alpha=$ .97 , in 1996; $\alpha=.95$, in 1998).

Principled objections to affirmative action. Two items measuring principled objections to affirmative action in the university context were included in both waves: (a) "Affirmative action admits too many students who have a low chance of academic success" and (b) "Affirmative action stigmatizes the people it's supposed to help." These two items measure concerns that have been central to recent public discourse on affirmative action in academic contexts (e.g., Connerly, 1996; Thernstrom \& Thernstrom, 1997). Responses were given on a 7-point scale ranging from 1 (strongly disagree) to 7 (strongly agree). Higher scores indicated greater endorsement of principled objections ( $\alpha=.71$, in 1996; $\alpha=.67$, in 1998).

\section{Results}

\section{Aggregate Trends: Racism, Conservatism, and Principled-Objection Endorsement}

Before the primary analyses were conducted, we computed mean values for each variable in 1996 and 1998, and we used paired-samples $t$ tests to see whether the means differed from one another. These values are shown in Table 5. As the entries in the first two rows indicate, scores on both of the variables presumed to

Table 5

Means for Each Variable in 1996 and 1998 (Study 2, University of California, Los Angeles Panel Study of Intergroup Attitudes)

\begin{tabular}{lcccccccc}
\hline & \multicolumn{2}{c}{1996} & & \multicolumn{2}{c}{1998} & & \\
\cline { 2 - 3 } \multicolumn{1}{c}{ Variable } & $M$ & $S D$ & & $M$ & $S D$ & & $t(371)^{\mathrm{a}}$ & $p$ \\
\hline Racism & 1.75 & 1.34 & & 1.49 & 1.00 & 3.84 & $<.001$ \\
Conservatism & 3.67 & 1.59 & & 3.55 & 1.58 & 2.22 & $<.05$ \\
Principled objections & 4.28 & 1.41 & & 3.91 & 1.51 & 4.52 & $<.001$ \\
\hline
\end{tabular}

a Pair-samples $t$ tests on the difference between each variable's means in 1996 and 1998. drive support for principled objections-racism and conservatism-declined significantly over the 2 years studied, although this decline was more marked in the case of respondents' racism scores. Moreover, principled objections also declined significantly over the course of the study, as indicated by the entries in the bottom row of Table 5. Although a tendency toward liberalization was thus found on all three variables, the results for racism are particularly interesting, because they reinforce the notion that education leads to lower absolute levels of prejudice (see Sniderman et al., 1991; see also McClosky \& Zaller, 1984). However, as described below, the effects of the college experience on the relationship between racism and principled objections were far less indicative of a liberalizing tendency, suggesting that education may strengthen the impact of racism on Whites' policy reasoning while simultaneously reducing absolute levels of racism.

\section{Education and the Antecedents of Principled Objections: A Longitudinal Analysis}

To compare the relationships between principled objections and each of our two predictors at the outset and after 2 years of college, we tested a maximum-likelihood LISREL structural equation model with latent factors corresponding to the 1996 and 1998 assessments of each variable; the full correlation matrix for this analysis is provided in the Appendix. Just as the multigroup latent-variable models tested in Study 1 allowed us to avoid the problems potentially created by different levels of measurement error across the two education groups, the use of latent factors in this model allowed us to avoid problems created by different levels of measurement error across the two panels of the study. The overall model, along with unstandardized estimates, is shown in Figure 2. In both waves, principled objections were assumed to be a function of conservatism and racism. Moreover, conservatism, racism, and principled objections after 2 years of college were assumed to be influenced by their counterparts at the outset of college; these relationships are indicated by the paths from each variable in 1996 to its counterpart in 1998. Finally, to capture cross-sectional covariance between conservatism and racism at each stage of the students' educational experience, the 1996 conservatism and racism factors were allowed to correlate, and the disturbances for the 1998 conservatism and racism factors were allowed to correlate as well (see Jöreskog \& Sörbom, 1993). On the whole, the model provided a good fit to the data, $\chi^{2}(45)=$ $119.85, p=.10$, AGFI $=.90$.

Looking at the unstandardized parameter estimates for the relationships between the two independent variables and principled objections in each wave, we found a pattern of results that was largely inconsistent with the principled-conservatism model's predictions about the effects of higher education. At the outset of college-when abstract political beliefs should not yet be fully developed and affective considerations like prejudice should have greater sway-conservatism was related to principled objections $(b=.35, p<.05)$, whereas racism was not $(b=.06, p>.10)$. However, after 2 years of college — by which time the educational process should have strengthened students' race-neutral political beliefs and diminished the effects of prejudicial considerationsthe effects of conservatism had actually decreased somewhat $(b=$ $.19, p<.05)$, whereas the effects of racism had increased substantially $(b=.30, p<.05)$ despite the aforementioned decline in 


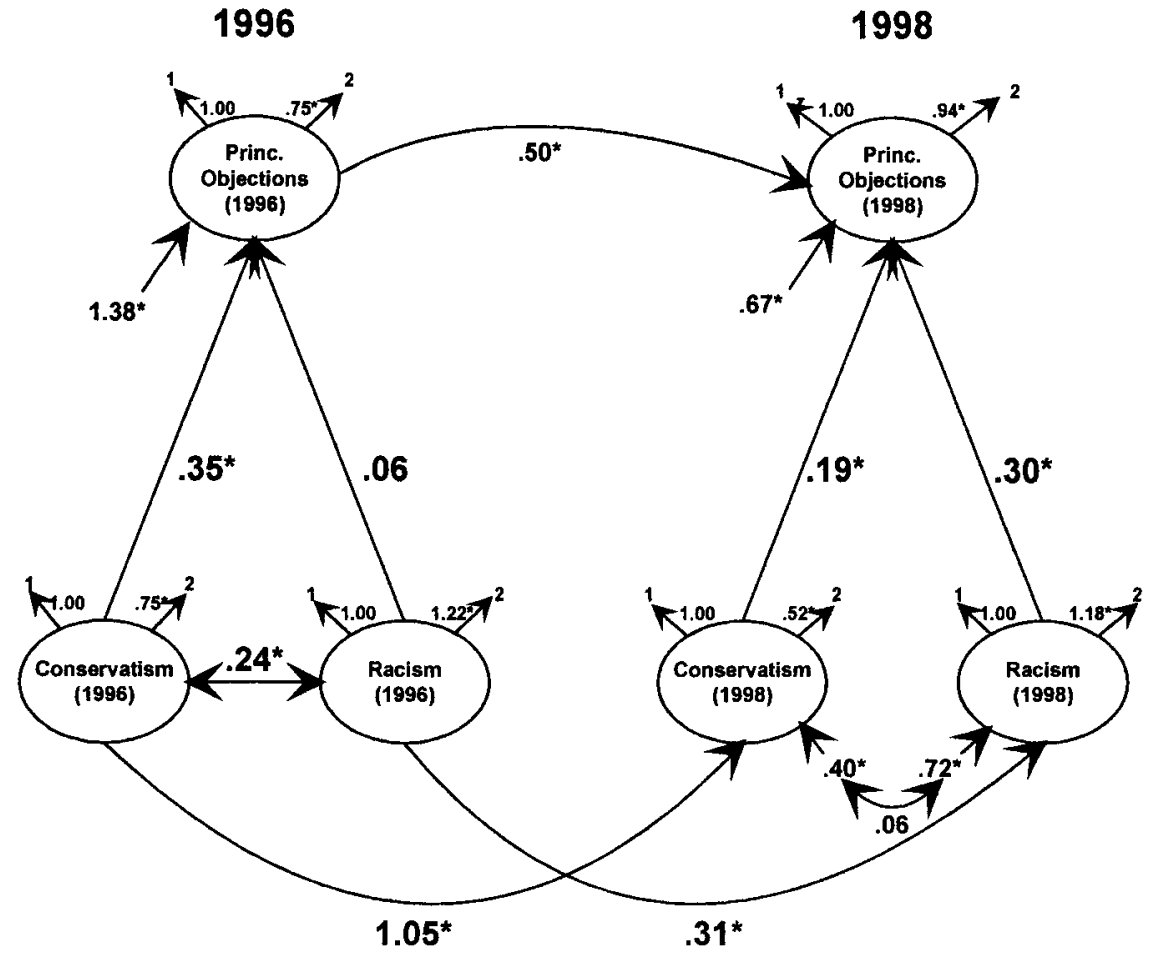

Figure 2. Conservatism and racism as predictors of principled objections at different stages of the college experience (Study 2, University of California, Los Angeles Panel Study of Intergroup Attitudes). Princ. = principled. $\chi^{2}(45)=119.85, p=.10$, adjusted goodness-of-fit index $=.90 .{ }^{*} p<.05$.

respondents' absolute levels of racism. Also, as one might expect, each variable after 2 years of college was related to its counterpart at the outset of college $(b=1.05, p<.05$, for conservatism; $b=$ $.31, p<.05$, for racism).

To confirm the reliability of this pattern, we reestimated the model twice, constraining the two paths from conservatism to principled objections to equality on the first run and the two paths from racism to principled objections to equality on the second run. When the relationship between conservatism and principled objections was constrained to equality across the two waves, the overall fit of the model declined, $\chi^{2}(46)=124.65, p<.0001$, with $\Delta \chi^{2}(1)=4.80, p<.05$, suggesting that the decrease in the magnitude of this relationship over time was reliable. Moreover, when the relationship between racism and principled objections was constrained to equality across the two waves, the overall fit of the model again declined significantly, $\chi^{2}(46)=125.08, p<$ .0001 , with $\Delta \chi^{2}(1)=5.23, p<.05$, suggesting that the aforementioned increase in the effect of racism on principled objections was a reliable one.

As such, this longitudinal comparison bolsters the conclusions suggested by the cross-sectional comparison described in Study 1. Although the completion of 2 years of college did lead to lower absolute levels of prejudice, it also appeared to strengthen the relationship between racism and principled objections over time, as the group-dominance model would predict. However, contrary to predictions made by the principled-conservatism model, higher education did not strengthen the relationship between conservatism and principled objections to affirmative action; in fact, it appeared to weaken it. Thus, in addition to providing further evidence for the dominance approach, these results also reinforce the notion that education may have paradoxical effects with regard to expressions of group dominance, reducing their overall intensity, on one hand, while simultaneously boosting their impact on policy reasoning.

\section{General Discussion}

In contrast to almost all past research in this area, rather than being focused on the determinants of affirmative action attitudes themselves, this study was primarily focused on the specific arguments people have in mind when opposing the policy and the role of education in determining what the antecedents of support for these arguments are. In two studies, we examined the role of these "principled objections" from two very different perspectives: the principled-conservatism approach and the general group-dominance approach.

Although the results of these studies lent a certain amount of support to each perspective, most of our findings were more consistent with the group-dominance model than the principledconservatism model. Consistent with what both models would predict, our results first of all suggested that principled objections were strongly related to actual opposition to affirmative action, even after the effects of several broader predispositions were taken into account. Moreover, consistent with the principled-conservatism model, we found that conservatism and individualism were independently predictive of principled objections, even after the 
effects of the group-dominance variables were considered. However, contrary to the expectations of the principled-conservatism model, our results indicated that the three dominance-related variables had effects of their own on principled objections. Moreover, although a causal analysis did suggest that one of the race-neutral variables (i.e., individualism) had an indirect effect on opposition to affirmative action via principled objections, it indicated that these objections serve as a pathway for the indirect effects of group dominance as well (see also Bobocel et al., 1998).

More uniquely, our results also suggested that the predictive power of these antecedents of principled objections varied with education. Although education had little or no effect on the relationship between political values and principled objections to affirmative action in our Los Angeles County sample, it did appear to strongly increase the effects of the three group-dominance variables. Bolstering this finding in an important way, the UCLA panel data showed a similar pattern of results in a longitudinal context. Whereas the relationship between conservatism and principled objections to affirmative action actually decreased as students completed additional years of college, the strength of the relationship between racism and principled objections increased over time. ${ }^{7}$ As noted earlier, these results suggest that education may have paradoxical effects on expressions of racism and group dominance. On the one hand, there is a sizable body of evidence suggesting that direct expressions of racism tend to decrease with increasing levels of education (e.g., Kahn, 1951; Lipset, 1960; McClosky \& Zaller, 1984; Sidanius et al., 1991; Sinclair, Sidanius, \& Levin, 1998). At the same time, however, it is also now clear that generalized predispositions (e.g., conservatism), policyrelevant issue considerations (e.g., principled objections), and racial-policy attitudes (e.g., opposition to affirmative action) become more strongly linked to racism and other expressions of group dominance as people become more educated. Thus, although educated Whites may be less likely to possess explicitly racist attitudes, they may also find it easier to connect the dominance-related motives they do possess with other attitudes (see Jackman, 1978; Jackman \& Muha, 1984).

Taken together, the results of these studies both reinforce and expand on other analyses. First of all, like earlier research (Federico \& Sidanius, 2000; Sidanius et al., 1996, 2000), the findings reported here suggest that racism and other expressions of group dominance are clearly germane to policy-relevant attitudes and that education strengthens this tendency. Unlike these analyses, however, the present study also suggests that group dominance has an important influence on even the specific, ostensibly race-neutral policy considerations Whites have in mind when opposing policies like affirmative action. Moreover, like important experimental work by Bobocel et al. (1998), the analyses reported here also suggest that these "principled" objections may in fact mediate the relationship between prejudicial considerations and affirmative action attitudes highlighted by these previous studies. Nevertheless, the studies reported here were able to go beyond this basic finding in a number of ways, by taking into account the role of the broader political predispositions behind the justice beliefs examined by Bobocel et al.; by examining a broader range of elitederived objections people may have in mind when thinking about affirmative action; by examining principled-objection endorsement under baseline conditions in which respondents were not encouraged to think about affirmative action in specific ways; and perhaps most important, by exploring the moderating role of education, a variable that has become the focal point for much of the academic debate about the antecedents of White opposition to policies like affirmative action. Finally, unlike almost all previous studies in this area, our panel study provided us with a developmental look at the effects of education, showing not only that the influence of racism and other expressions of group dominance differs across educational levels in the predicted fashion but also that the changes that produce these differences can actually be tracked over the course of the educational experience.

Despite the fact that these accumulated results provide a consistent pattern of support for the group-dominance position, we would like to make it clear what we are not saying. Namely, we are not rejecting the principled-conservatism perspective in its entirety. A number of its arguments have found support in studies conducted by theorists from a variety of backgrounds (see Bobocel et al., 1998; Sears et al., 1997; Sidanius et al., 1996, 2000). The most important of these arguments is that White opposition to race-targeted social policies is not merely a function of racism or other expressions of group dominance. That is, it is clear that these policies are also opposed for abstract reasons that have little or nothing to do with the dominance-oriented motives highlighted here. Moreover, it is also clear that these race-neutral motives are often more powerfully related to affirmative-action opposition among the educated, a finding consistent with a long line of research on ideological constraint (see Converse, 1964; see also Bishop, 1976; Judd \& Krosnick, 1989; Stimson, 1975; Zaller, 1992).

Nevertheless, we still believe that the principled-conservatism approach suffers from a number of serious problems. These limitations are not only illustrated by the fact that opposition to affirmative action is more strongly associated with desires for group dominance among the well-educated but also by the fact that principled objections to affirmative action are themselves more strongly associated with dominance-related motives among the well-educated. These facts, taken together with the finding that principled objections may simply serve as a conduit for the effects of motives which are far from race-neutral, cast serious doubt on key aspects of the principled-conservatism thesis. We submit that rather than being opposed merely because it violates tenets of the American creed, affirmative action is also opposed because it is thought to endanger the continued hegemony of one group over another and that ostensibly principled objections to the policy may serve as a mask for the effects of this motive.

Although a broad pattern of results would thus appear to provide support for the assumptions of the general group-dominance model, we would also like to point out a few unresolved issues. First of all, although we and others (e.g., Bobocel et al., 1998) have argued that principled objections should be seen as antecedents of opposition to the policy itself, there is good reason to suspect that the causal arrow may point in the opposite direction as well. That

\footnotetext{
${ }^{7}$ Moreover, this residual effect of higher education is even more impressive when one remembers that the respondents - all high school graduates-were already more thoroughly educated at the outset of the study than many of the individuals typically categorized as "poorly educated" in previous studies (e.g., those without high school degrees; see Sidanius et al., 1996; Sniderman et al., 1991).
} 
is, once people have decided they are against affirmative action, for whatever reason, they may then fall back on "principled" arguments found in elite discourse to justify this a priori position. Our evidence does not exclude the possibility of such effects, which may in fact coexist with the ones described above. However, measures of both affirmative action and principled objections were available only in our cross-sectional dataset from Study 1, which made it impossible to disentangle these two causal scenarios from one another (which would require a cross-lagged analysis of longitudinal data on both measures; see Markus, 1979). As such, additional data will be required before this question can be adequately addressed.

Moreover, as we have noted elsewhere (Federico \& Sidanius, 2000), although there is now consistent evidence that dominance motives strongly predict opposition to race-targeted policies among the educated and other sophisticated portions of the mass public, this moderating effect has yet to be tested using the population of "true political elites," including government officials, activists, journalists, and academics (cf. Converse, 1964; McClosky \& Zaller, 1984). As such, it is still possible that the principled-conservatism perspective might apply in this very select group of political actors, among which principled opposition to affirmative action appears to have resonated strongly (e.g., Connerly, 1996; Glazer, 1975; Thernstrom \& Thernstrom, 1997). These issues and others await the attention of researchers.

\section{References}

Altemeyer, B. (1998). The other "authoritarian personality." In M. P. Zanna (Ed.), Advances in experimental social psychology (Vol. 30, pp. 48-92). New York: Academic Press.

Ansell, A. E. (1997). New right, new racism. New York: New York University Press.

Bennett, S. (1988). "Know-nothings" revisited: The meaning of political ignorance today. Social Science Quarterly, 69, 476-490.

Biernat, M., \& Crandall, C. S. (1999). Racial attitudes. In J. P. Robinson, P. R. Shaver, \& L. S. Wrightsman (Eds.), Measures of political attitudes (pp. 297-411). San Diego, CA: Academic Press.

Bishop, G. (1976). The effect of education on ideological consistency. Public Opinion Quarterly, 40, 337-348.

Blumer, H. (1961). Race prejudice as a sense of group position. In J. Masuoka \& P. Valien (Eds.), Race relations: Problems and theory (pp. 217-227). Chapel Hill: University of North Carolina Press.

Bobo, L. (1983). Whites' opposition to busing: Symbolic racism or realistic group conflict? Journal of Personality and Social Psychology, 45, 11951210.

Bobo, L. (1988). Group conflict, prejudice, and the paradox of contemporary racial attitudes. In P. A. Katz \& D. A. Taylor (Eds.), Eliminating racism: Profiles in controversy (pp. 85-114). New York: Plenum.

Bobo, L. (2000). Race and beliefs about affirmative action. In D. O. Sears, J. Sidanius, \& L. Bobo (Eds.), Racialized politics: Values, ideology, and prejudice in American public opinion (pp. 137-164). Chicago: University of Chicago Press.

Bobocel, D. R., Son Hing, L. S., Davey, L. M., Stanley, D. J., \& Zanna, M. P. (1998). Justice-based opposition to social policies: Is it genuine? Journal of Personality and Social Psychology, 75, 653-669.

Campbell, A., Converse, P. E., Miller, W. E., \& Stokes, D. E. (1960). The American voter. New York: Wiley.

Carmines, E. G., \& Merriman, R. W., Jr. (1993). The changing American dilemma: Liberal values and racial policies. In P. M. Sniderman, P. E. Tetlock, \& E. G. Carmines (Eds.), Prejudice, politics, and the American dilemma (pp. 237-255). Stanford, CA: Stanford University Press.
Carmines, E. G., \& Stimson, J. A. (1989). Issue evolution: Race and the transformation of American politics. Princeton, NJ: Princeton University Press.

Citrin, J., \& Green, D. P. (1990). The self-interest motive in American public opinion. In S. Long (Ed.), Research in micropolitics (Vol. 3, pp. 1-28). Greenwich, CT: JAI Press.

Connerly, W. (1996). With liberty and justice for all (Heritage Lecture No. 560). Retrieved from http://www.heritage.org/library/categories/ crimelaw/lect560.html

Converse, P. E. (1964). The nature of belief systems in mass publics. In D. E. Apter (Ed.), Ideology and discontent (pp. 206-261). London: Collier-Macmillan.

Delli Carpini, M. X., \& Keeter, S. (1996). What Americans know about politics and why it matters. New Haven, CT: Yale University Press.

Federico, C. M. (2000). Predispositions, sophistication, and the framing of affirmative action. Manuscript submitted for publication.

Federico, C. M., \& Sidanius, J. (2000). The "cognizati caveat": Racism, ideology, and affirmative action in America. Manuscript submitted for publication.

Gamson, W. A. (1992). Talking politics. Cambridge, England: Cambridge University Press.

Gamson, W. A., \& Modigliani, A. (1987). The changing culture of affirmative action. In R. G. Braungart \& M. M. Braungart (Eds.), Research in political sociology (pp. 137-177). Greenwich, CT: JAI Press.

Glazer, N. (1975). Affirmative discrimination. New York: Basic Books.

Gramsci, A. (1976). Selections from the prison notebooks (Q. Hoare \& G. Smith, Trans.). New York: International Publishers. (Original work published 1948)

Jackman, M. R. (1978). Education and policy commitment to racial integration. American Journal of Political Science, 22, 302-324.

Jackman, M. (1994). The velvet glove: Paternalism and conflict in gender, class, and race relations. Berkeley: University of California Press.

Jackman, M. R., \& Muha, M. J. (1984). Education and intergroup attitudes: Moral enlightenment, superficial democratic commitment, or ideological refinement? American Sociological Review, 49, 751-769.

Jacoby, T. (1994, January 24). After bigotry. The New Republic, 123, $36-38$.

Jöreskog, K. G., \& Sörbom, D. (1993). LISREL 8 user's manual [Computer software and manual]. Chicago: Scientific Software International.

Judd, C. M., \& Downing, J. W. (1990). Political expertise and the development of attitude consistency. Social Cognition, 8, 104-124.

Judd, C. M., \& Krosnick, J. A. (1989). The structural bases of consistency among political attitudes: Effects of expertise and attitude importance. In A. R. Pratkanis, S. J. Breckler, \& A. G. Greenwald (Eds.), Attitude structure and function (pp. 99-128). Hillsdale, NJ: Erlbaum.

Judd, C. M., Krosnick, J. A., \& Milburn, M. A. (1981). Political involvement and attitude structure in the general public. American Sociological Review, 46, 660-669.

Judd, C. M., \& Milburn, M. A. (1980). The structure of attitude systems in the general public: Comparisons of a structural equation model. American Sociological Review, 45, 627-643.

Kahn, L. A. (1951). The organization of attitudes toward the negro as a function of education. Psychological Monograph, 65, 39.

Kinder, D. R., \& Sanders, L. M. (1990). Mimicking political debate with survey questions: The case of white opinion on affirmative action. Social Cognition, 8, 73-103.

Kinder, D. R., \& Sanders, L. M. (1996). Divided by color: Racial politics and democratic ideals. Chicago: University of Chicago Press.

Lavine, H., Thomsen, C. J., \& Gonzales, M. H. (1997). The development of interattitudinal consistency: The shared consequences model. Journal of Personality and Social Psychology, 72, 735-749.

Lipset, S. M. (1960). Political man. New York: Doubleday.

Markus, G. B. (1979). Analyzing panel data. Beverly Hills, CA: Sage. 
Marx, K., \& Engels, F. (1970). The German ideology (C. J. Arthur, Trans.). New York: International Publishers. (Original work published 1846)

McClosky, H., \& Zaller, J. (1984). The American ethos. Cambridge, MA: Harvard University Press.

McConahay, J. B. (1983). Modern racism and modern discrimination: The effects of race, racial attitudes, and context on simulated hiring decisions. Personality Social Psychology Bulletin, 9, 551-558.

McFarland, S. G., \& Adelson, S. (1996, July). An omnibus study of personality, values and prejudices. Paper presented at the annual convention of the International Society for Political Psychology, Vancouver, British Columbia, Canada.

Murphy, R., \& Gulliver, H. (1971). Southern strategy. New York: Charles Scribner's Sons.

Pedhazur, E. J. (1997). Multiple regression in behavioral research. Fort Worth, TX: Harcourt Brace College.

Pettigrew, T. F., \& Meertens, R. W. (1995). Subtle and blatant prejudice in Western Europe. European Journal of Social Psychology, 25, 221-239.

Pratto, F., Sidanius, J., Stallworth, L. M., \& Malle, B. F. (1994). Social dominance orientation: A personality variable predicting social and political attitudes. Journal of Personality and Social Psychology, 67, 741-763.

Roth, B. M. (1990). Social psychology's racism. Public Interest, 27, 155-171.

Schuman, H., Steeh, C., Bobo, L., \& Krysan, M. (1997). Racial attitudes in America: Trends and interpretations (Rev. ed.). Cambridge, MA: Harvard University Press.

Sears, D. O. (1988). Symbolic racism. In P. A. Katz \& D. A. Taylor (Eds.), Eliminating racism: Profiles in controversy (pp. 53-84). New York: Plenum.

Sears, D. O., Henry, P. J., \& Kosterman, R. (2000). Egalitarian values and contemporary racial politics. In D. O. Sears, J. Sidanius, \& L. Bobo (Eds.), Racialized politics: Values, ideology, and prejudice in American public opinion (pp. 75-117). Chicago: University of Chicago Press.

Sears, D. O., Hetts, J. J., Sidanius, J., \& Bobo, L. (2000). Race in American politics. In D. O. Sears, J. Sidanius, \& L. Bobo (Eds.), Racialized politics: Values, ideology, and prejudice in American public opinion (pp. 1-43). Chicago: University of Chicago Press.

Sears, D. O., van Laar, C., Carrillo, M., \& Kosterman, R. (1997). Is it really racism? Theories of White Americans' opposition to race-targeted policies. Public Opinion Quarterly, 61, 16-53.

Selznick, G., \& Steinberg, S. (1969). The tenacity of prejudice: AntiSemitism in contemporary America. New York: Harper \& Row.

Sherif, M. (1966). Group conflict and cooperation: Their social psychology. London: Routledge \& Kegan Paul.

Sidanius, J. (1993). The psychology of group conflict and the dynamics of oppression: A social dominance perspective. In S. Iyengar \& W. McGuire (Eds.), Explorations in political psychology (pp. 183-219). Durham, NC: Duke University Press.

Sidanius, J., \& Pratto, F. (2001). Social dominance: An intergroup theory of social hierarchy and oppression. New York: Cambridge University Press.

Sidanius, J., Pratto, F., \& Bobo, L. (1996). Racism, conservatism, affirmative action, and intellectual sophistication: A matter of principled conservatism or group dominance? Journal of Personality and Social Psychology, 70, 476-490.

Sidanius, J., Pratto, F., Martin, M., \& Stallworth, L. (1991). Consensual racism and career track: Some implications of social dominance theory. Political Psychology, 12, 691-721.

Sidanius, J., Singh, P., Hetts, J., \& Federico, C. (2000). It's not affirmative action, it's the Blacks: The continuing relevance of race in American politics. In D. O. Sears, J. Sidanius, \& L. Bobo (Eds.), Racialized politics: Values, ideology, and prejudice in American public opinion (pp. 183-219). Chicago: University of Chicago Press.

Sinclair, S., Sidanius, J., \& Levin, S. (1998). The interface between ethnic and social system attachment: The differential effects of hierarchyenhancing and hierarchy-attenuating environments. Journal of Social Issues, 54, 741-757.

Smith, A. W. (1981). Racial tolerance as a function of group position. American Sociological Review, 46, 558-573.

Sniderman, P. M., Brody, R. A., \& Kuklinski, J. H. (1984). Policy reasoning and political values: The problem of racial equality. American Journal of Political Science, 28, 75-94.

Sniderman, P. M., \& Carmines, E. G. (1997). Reaching beyond race. Cambridge, MA: Harvard University Press.

Sniderman, P. M., Crosby, G. C., \& Howell, W. G. (2000). The politics of race. In D. O. Sears, J. Sidanius, \& L. Bobo (Eds.), Racialized politics: Values, ideology, and prejudice in American public opinion (pp. 236279). Chicago: University of Chicago Press.

Sniderman, P. M., Hagen, M. G., Tetlock, P. E., \& Brady, H. E. (1986). Reasoning chains: Causal models of policy reasoning in mass publics. British Journal of Political Science, 16, 405-430.

Sniderman, P. M., \& Piazza, T. (1993). The scar of race. Cambridge, MA: Harvard University Press.

Sniderman, P. M., Piazza, T., Tetlock, P. E., \& Kendrick, A. (1991). The new racism. American Journal of Political Science, 35, 423-447.

Stimson, J. A. (1975). Belief systems: Constraint, complexity, and the 1972 election. American Journal of Political Science, 19, 393-418.

Thernstrom, S., \& Thernstrom, A. (1997). America in black and white: One nation indivisible. New York: Simon \& Schuster.

Turner, J. H., Singleton, R., Jr., \& Musick, D. (1984). Oppression: A socio-history of Black-White relations in America. Chicago: Nelson Hall.

van den Berghe, P. (1967). Race and racism. New York: Wiley.

Whitley, B. E., Jr. (1999). Right-wing authoritarianism, social dominance orientation, and prejudice. Journal of Personality and Social Psychology, 77, 126-134.

Zaller, J. (1992). The nature and origins of mass opinion. New York: Cambridge University Press. 
Appendix

Correlations Between Latent-Variable Indicators, Study 2

\begin{tabular}{|c|c|c|c|c|c|c|c|c|c|c|c|c|}
\hline Latent indicator & 1 & 2 & 3 & 4 & 5 & 6 & 7 & 8 & 9 & 10 & 11 & 12 \\
\hline \multicolumn{13}{|l|}{1996 measures } \\
\hline 1. Party identification & - & & & & & & & & & & & \\
\hline 2. Ideology & .77 & - & & & & & & & & & & \\
\hline 3. Interethnic dating & $.06^{\mathrm{a}}$ & $.08^{\mathrm{a}}$ & - & & & & & & & & & \\
\hline 4. Interethnic marriage & $.09^{\mathrm{a}}$ & .11 & .94 & - & & & & & & & & \\
\hline 5. AA admits unprepared students & .43 & .33 & .13 & .14 & - & & & & & & & \\
\hline 6. AA stigmatizes recipients & .33 & .33 & $.01^{\mathrm{a}}$ & $.06^{\mathrm{a}}$ & .55 & - & & & & & & \\
\hline \multicolumn{13}{|l|}{1998 measures } \\
\hline 7. Party identification & .80 & .73 & $.06^{\mathrm{a}}$ & $.10^{\mathrm{a}}$ & .30 & .25 & - & & & & & \\
\hline 8. Ideology & .55 & .60 & $.06^{\mathrm{a}}$ & $.08^{\mathrm{a}}$ & .16 & .18 & .62 & - & & & & \\
\hline 9. Interethnic dating & .11 & $.07^{\mathrm{a}}$ & .38 & .40 & $.10^{\mathrm{a}}$ & $.03^{\mathrm{a}}$ & $.10^{\mathrm{a}}$ & .13 & - & & & \\
\hline 10. Interethnic marriage & .14 & .13 & .36 & .43 & .14 & $.07^{\mathrm{a}}$ & .15 & .12 & .91 & - & & \\
\hline 11. AA admits unprepared students & .34 & .32 & .12 & .14 & .42 & .21 & .33 & .34 & .26 & .27 & - & \\
\hline 12. AA stigmatizes recipients & .34 & .31 & $.00^{\mathrm{a}}$ & $.04^{\mathrm{a}}$ & .34 & .33 & .32 & .35 & .18 & .18 & .50 & - \\
\hline
\end{tabular}

Note. $\mathrm{AA}=$ affirmative action.

${ }^{a}$ Correlations not significant at the $p<.05$ level.

\section{Low Publication Prices for APA Members and Affiliates}

Keeping you up-to-date. All APA Fellows, Members, Associates, and Student Affiliates receive-as part of their annual dues-subscriptions to the American Psychologist and APA Monitor. High School Teacher and International Affiliates receive subscriptions to the APA Monitor, and they may subscribe to the American Psychologist at a significantly reduced rate. In addition, all Members and Student Affiliates are eligible for savings of up to $60 \%$ (plus a journal credit) on all other APA journals, as well as significant discounts on subscriptions from cooperating societies and publishers (e.g., the American Association for Counseling and Development, Academic Press, and Human Sciences Press).

Essential resources. APA members and affiliates receive special rates for purchases of APA books, including the Publication Manual of the American Psychological Association, and on dozens of new topical books each year.

Other benefits of membership. Membership in APA also provides eligibility for competitive insurance plans, continuing education programs, reduced APA convention fees, and specialty divisions.

More information. Write to American Psychological Association, Membership Services, 750 First Street, NE, Washington, DC 20002-4242. 